\title{
Bone marrow stem cells and their role in angiogenesis
}

\author{
Célulastronco da medula óssea e seu papel na angiogênese
}

\section{Paulo Eduardo 0 cke Reis*}

\begin{abstract}
The degree of symptomatology of a patient with peripheral arterial disease dictates the kind of treatment. D espite the known therapies, some patients continue to have pain with ambulation, which affects their quality of life. The therapeutic implications of the angiogenic growth factors were identified by the pioneering studies of Folkman et al. 2 decades ago. Further investigations established the possibility of the use of formulations of recombinant angiogenic growth factors, with the objective of developing or increasing the network of collaterals in animal models of chronic myocardial or limb ischemia. Researches suggest that primitive stem cells with whole bone marrow possess greater functional plasticity, capable of contributing to regeneration of ischemic limb muscle and vascular endothelium by adult stem cells. Local autologous marrow stromal cells implantation induces a neovascular response resulting in a significant increase in blood flow to the ischemic limb. In this article we review the studies that have established how the implantation of bone marrow cells into ischemic limbs increases collateral vessel formation.
\end{abstract}

Key words: growth factor, angiogenesisfactor, stem cells, ischemia.

The present treatment of critical ischemia of the lower limbsconsistsof auniversal and aggressiveattempt to save the ischemic limb. In spite of the knowledge of the factors that contribute to the devel opment of lower limb ischemic disease, some limitations are found, mainly in the identification of the amputation risk population, and in the prevention of theadvance of the vascular disease. Therisk factorsidentified for peripheral arterial occlusive disease (PAOD) are essentially the same as for arteriosclerosis. Smoking patients present

\footnotetext{
* MD. Chief of Vascular Surgery, Hospital Antonio Pedro/Universidade Federal Fluminense, Rio de Janeiro, RJ. Vascular Surgeon, Hospital Pró-Cardíaco, RJ.
}

Article submitted on September 19, 2005, accepted on November 2, 2005.

J Vasc $\mathrm{Br}$ 2005:4(4):366-70.

Copyright $\odot 2005$ by Sociedade Brasileira de Angiologia e Cirurgia Vascular.

\section{Resumo}

0 nível de sintomatologia de um paciente com doença arterial periferal determina o tipo de tratamento. A pesar das terapias conhecidas, al guns pacientes continuam a ter dor com a deambulação, o que afeta sua qualidade de vida. As implicações terapêuticas dos fatores de crescimento angiogênicos foram identificadas por estudos pioneiros de Folkman et al. há 2 décadas. Investigações posteriores estabeleceram a possibilidade de utilizar formulações de fatores de crescimento angiogênico recombinantes, com o objetivo de desenvolver ou aumentar a rede de colaterais em modelos animais de isquemia crônica ou miocárdica. Pesquisas sugerem que células-tronco primitivas com medula óssea possuem maior funcionalidade plástica, capazes de contribuir com a regeneração de músculos isquêmicos e endotélio vascular por células-tronco adultas. 0 implante local e autólogo de células estromais da medula induz a uma resposta neovascular, resultan do em um aumento significativo de fluxo sangüíneo no membro isquêmico. $\mathrm{N}$ este artigo, revisamos os estudos que estabeleceram como o implante de células da medula óssea em membros isquêmicos aumenta a formação de vasos colaterais.

Palavras-chave: fator de crescimento, fator de angiogênese, células-tronco, isquemia.

threetimes morerisk of developing ischemic symptoms in thelower limbs than non-smoking patients. Patients with diabeteshavetwicetherisk of developing peripheral arterial disease, compared to non-diabetic patients. Resistance to insulin, glucose intolerance and hyperinsulinism wereconsidered risk factorsfor PAOD. Also, the association of hypertriglyceridemia with the progression of carotid and coronary arteriosclerosis is well established. ${ }^{1}$ The role of systemic arterial hypertension in the development of PAOD isdebatable, with the Framingham and Finnish studies reaching opposite conclusions. It is known that the aggressive control of blood pressure in recently diagnosed hypertensive patients can reduce perfusion, causing decompensation of the limb, making it symptomatic. W hen therisk factorsabovecoexist, therisk of developing PAOD substantially increases. It is important to stress thegrowing mortality in thepopulation with peripheral 
vascular disease due to the influence of the ischemic limb on the cardiovascular system.

The main clinical manifestation of the disease is intermittent claudication. In a period of 5 to 10 years, about $70 \%$ of these patients will remain asymptomatic or oligosymptomatic, but 20 to $30 \%$ will show progressive symptoms and have indications of arterial revascularization. Some 15 to $20 \%$ will evolve from intermittent claudication to critical limb ischemia, and about 5 to $10 \%$ will have indication of amputation, with an incidence of lessthan $4 \%$ for major amputation.

N umerically, about 3,200 to 4,800 people/ $1,000,000$ inhabitants/year will besubjected to a major amputation. Thepresenceof diabetesmellitusrepresents the greatest risk, and the association of this with the use of tobacco provides a faster evolution. D ormandy et al. demonstrated that an ankle-arm index ( $A B I)$ of 0.5 in the initial diagnosis is the most significant prognostic indicator for the PAOD deterioration and the need for intervention. ${ }^{2}$

For the various steps in the progress of arterial disease there are different therapeutic behaviors. O ligosymptomatic or thosewith claudication that does not generate alterations in the everyday life should be treated conservatively through habit modification and the use of vasoactive medication.

Whereas patients with incapacitating claudication for short distances show a great restriction in their habits, patients showing pain when at rest or with ischemic lesions in the lower limbs are candidates for revascularization.

M orerecently, alternativesrelated to cellular therapy started to be developed. In the last 4 years, somein vitro and in vivo studies have been published, suggesting the potential of the use of stem cells (SC) for this purpose. The autologous transplantation of bone marrow mononuclear cells (ATBM MC) has shown great therapeutic potential in vitro as well as in vivo. Angiogenesis induced by thetreatment with stem cells, coupled with thepracticeof exercisesand pharmaceutical therapy can be a therapeutic alternative for patients with PAOD.

\section{Clinical trials}

The therapeutic implications of the angiogenic growth factorswereidentified by the pioneering studies of Folkman et al. 2 decadesago. ${ }^{3}$ Further investigations established the possibility of the use of formulations of recombinant angiogenic growth factors, with the objective of developing or increasing the network of collaterals in animal models of chronic myocardial or limb ischemia. Thisnew strategy wascalled angiogenesis. T akeshida et al. ${ }^{4}$ investigated the hypothesis that the vascular endothelial growth factor (phVEGF) was sufficient to constitute a therapeutic effect. $H$ is group used asingleintraarterial bolus of VEG F and established proof of the angiogenic activity of VEGF in a rabbit ischemic hindlimb model. ${ }^{4}$ Preclinical findings suggest that intraarterial genetransfer of a plasmid can improve blood supply to theischemic limb. Thegenictransfection in humans using DN A bearing phVEG F was initially carried out successfully for treating patients with severe limb ischemia. ${ }^{5}$ Three patients with pain at rest and treated with 1,000 $\mu \mathrm{g}$ phVEG F evolved with improved symptoms and arterial flux for the treated member, after a 1-year follow-up. W ith the dosage increased to 2,000 $\mu \mathrm{g}$, angiographic and histologic evidence of vascular neoformation became evident. The interpretation is that the administration of endothelial cells mitogens promotes angiogenesis in patients with limb ischemia. ${ }^{5}$ T hoseinvestigatorstested thehypothesis that endothelial nitric oxide synthase modulates angiogenesisin two rabbit ischemic hindlimb model, in which therapeutic angiogenesis has been showed as a compensatory responseto tissueischemia. Angiogenesis in the ischemic hindlimb was improved; there was angiographical evidence of vascularity in the limb. ${ }^{6}$

Precursor endothelial cells, originating in the bone marrow, could beidentified as CD 34+and VEGFR2+, although other markers such as AC 133+ and CD 31+ have been described. D uring the tissue ischemia, with a drop in the oxygen levels, there is an increase in the production of H IF-1, which in its turn will unleash the increase of several growth factors, notably VEGF. Asahara et al. isolated putative endothelial cell progenitors from peripheral blood by magnetic bead selection on the basis of cell surface CD 34+ antigen expression that becamespindle-shaped endothelial cells and proliferated for 4 weeks. ${ }^{7}$ Bone marrow contains pluripotent CD $34+$ cells, which are known to give rise to hematopoietic cells. In vitro studies show that they can differentiate into mature endothelial cells. ${ }^{7,8} \mathrm{~A}$ study demonstrated in the dog that CD 34+cells seeded into grafts could enhance vascular graft endothelialization and vessel formation. ${ }^{9}$

0 ther alternatives have been developed based on the conceptual notion that endothelial cells and 
hematopoietic stem cells come from a common precursor: thehemangioblast. ${ }^{10} \mathrm{~T}$ herefore, theparadigm that endothelial cells were generated by replication of matureendothelial cellswasrevolutionized. Thisauthor observed that a great part of the cells involved in the process of angiogenesis had their origin in the bone marrow (BM). ${ }^{10}$

TheBM hasendothelial progenitor cellsthat secrete several growth factors and can contribute to the formation of new capillaries. Authors investigated the extent of angiogenesis induced by implantation of autologous cells. In a rat ischemic hindlimb model, using nonradioactive colored microspheres and by determiningthefemoral arteriovenousoxygen difference postligation at 2 weeks, they showed the severity of the ischemic insult. To assess angiogenesis, histologic evaluation and angiography weredone. They concluded that BM cells induced angiogenesis and improved deteriorated exercise capacity in the animal. ${ }^{11}$ Also, the angiogenic effect wasexamined in theischemichindlimb in a diabetic rat model. $D$ iabetes mellitus was induced by streptozotocin. ${ }^{12}$

Direct myocardial injection of phVEGF-A 165 was carried out successfully in five patients with coronary disease and no possibility of revascularization. ${ }^{13}$ A nother study carried out on seven patients suffering from chronic refractory angina, by means of a minithoracotomy, through transepicardiac injections, achieved the same objective. 0 ther studies with placebo controls were published in the USA. In 2002 the second genic therapy in humans (AGEN T), randomized, double blind and controlled by placebo, in patients with stableangina class C anadian II and III waspublished. The increase in VEG F will be the main stimulus for the mobilization of the BM cells as well as the main signal for homing these cells onto theischemic tissues, and their later differentiation into endothelial cells in tubular structures. ${ }^{14}$ T heapplication of VEGF for therapeutic neovascularization mobilizes the CPE. ${ }^{15}$

The first report of a case of the use of bone marrow stem cells (BM SC) was carried out by Dr. Bodum Strauer in August 2001, who safely carried out the injection of BM SC via coronary in a patient after IAM . Later $\mathrm{H}$ amano et al. reported five cases carried out in Japan, where the intramyocardial transplant of the BM SC wascarried out during revascularization surgery, where three of the five patients showed improved myocardial perfusion in the injected areas. ${ }^{16}$
Infusion of the gene of fibroblast growth factor (FGF) was carried out via intracoronary, using adenovirus as a vector (Ad5-FGF5) in 79 patients (19 received placebo), with symptom and contractility improvement in the treated group. ${ }^{17}$ Later in the same year another study was published: randomized, double blind, with placebo, with a scaled dose of phVEG F in 18 patients and placebo in nine patients, subjected to transendocardiac injections, also via N O GA injection catheter. ${ }^{13}$

These preliminary studies in animals and clinical tests have two implications: first, they suggest that the fundamental mechanism by which neovascularization increases the network of collaterals is through the supply of supplementary cytokine to individuals who, dueto their advanced age, diabetes, hypercholesterolemia and other still undefined circumstances, are unable to increase its supply in response to tissue ischemia. Recently, $\mathrm{H}$ eeschen et al. have shown that the ability to recruitstem cellsfrom thebonemarrow may beimpaired in certain older adults. ${ }^{18}$ Second, administering cytokine clearly represents only one factor of the therapeutic intervention. Independently of how much is administered, the population of resident endothelial cells capable of responding to a certain level of vascular growth factor can constitute a potential limiting factor for thestrategiesdesigned to promoteneovascularization in ischemic tissues.

The therapeutic angiogenesis with recombinant fibroblast growth factor- 2 for intermittent claudication (TRAFFIC) was the first clinical randomized study controlled by placebo that showed a positive effect of the treatment with fibroblast growth factor (FG F-2) in 180 patients with critical limb ischemia. ${ }^{19}$ Their hypothesis was that intra-arterial rFGF-2 increases exercise capacity in patients with moderate to severe intermittent claudication dueto infrainguinal peripheral artery disease.

To induce angiogenesis, investigators have delivered VEGF and basic fibroblast growth factor (bFGF), or hypoxia - inducible factor. In this study, it has become clear that the subsequent stage of remodeling and stabilization are crucial for attaining stable and functional vessels. ${ }^{20}$

Iba et al. ${ }^{20}$ clearly showed that intramuscular implantation of human peripheral blood mononuclear cells and platelets into ischemic limbs effectively inducescollateral vessel formation mainly by supplying VEGF. 
Al-Khaldi et al. evaluated the effect of local autologous bone marrow stromal cells to induce a neovascular response, after ligating the left common iliac artery of male Lewisrats, resulting in a significant increase in blood flow to the ischemic limb. Also, the ability of spontaneous regeneration of muscular tissues. $^{21}$

Cell-based therapy has the advantage that the implantation of asingleagent may result in thesustained production of multiple arteriogenic growth factors. ${ }^{22}$ T ateishi-Yuyama et al., in a clinical study using bone marrow cells, showed a sustained arteriogenic response with cell-based therapy. ${ }^{23}$

Furthermore, it opened the way to the discovery that there is vasculogenesis in adult life, i.e., that new vessels appear in adult life, not only the concept of replication of capillaries from existing vessels called angiogenesis. After its publication, others followed confirming these results. ${ }^{8,24}$

Recently it was demonstrated that the freeing of cytokines as VEGF and bFGF modulated by bone marrow cells remodel collateral circulation more actively than by direct cell incorporation. The spectrum of the genic expression of the cytokines by bone marrow cells is related to the paracrine mechanisms that support the biological effects of cell therapy for ischemic tissue.

This work showed that, although there was some degree of revascularization in the control group, the repeated injection of the conditioned medium induced a much more efficient angiogenic response.

This group admits that freeing the cytokines is sufficient to mediate arteriogenesis and collateral circulation after cell therapy. H owever, complementary mechanisms must contribute to the beneficial effect and the formation of blood vessels. The importance of the mechanism is still unknown. ${ }^{24}$

The first study during a myocardial revascularization surgery in humans was carried out with five patients, injecting stem cells in nonrevascularizableareas of themyocardium. Theresults showed that three of the five patients treated in that manner improved the myocardial perfusion after a year of following their development. Also, this confirmed theresults of previousexperimental studies in animal models, showing that therewereno harmful alterations in the hearts where the stem cells were injected.
In the T O PCARE study, carried out in Germany, theBM SC $(n=9)$ and theSC obtained from peripheral blood and expanded in vitro in culture $(n=11)$ were administered by intracoronary infusion 4 days after the IAM in patients that had been subjected to primary angioplasty. ${ }^{25}$ In Brazil research involving stem cells has seen important advances. The partnership of the H ospital Pró-Cardíaco of Rio de J aneiro with the T exas $\mathrm{H}$ eart Institute and the $U$ niversidade $F$ ederal do Rio de Janeiro, made possible a study with transendocardiac implantation by catheter of BM SC in patients with severe ischemic cardiopathy without the possibility of conventional myocardial revascularization. ${ }^{26}$

Fourteen patientsweresubjected to cellular therapy. The transplants were made with the use of NOGA catheters, and the procedures were carried out without major complications, so that all patientsweredischarged in 48 hours.

In a 2-month follow-up there was a significant improvement of the symptoms. Improvement of myocardial perfusion, with a reduction in the ischemic area from 15.1 to $4.5 \%$ in the LV (left ventricle) $(P=0.02)$, reduction in the final systolic volume of $15 \%(P=0.03)$ and relativeimprovement of $31 \%$ in the FE ( $P=0.0004)$.

O n August 2002 the first clinical study in humans waspublished, theautologoustransplant of bonemarrow mononuclear cells in 52 patients with chronic limb ischemia, through injections in the sural region, based on previous and experimental models of limb ischemia and myocardial ischemia. ${ }^{23}$

They noted that CD $31+$ endothelial cells express $\mathrm{ki}-67$ in the marrow-implanted limb. $\mathrm{Ki}$ is a nuclear protein that is expressed in proliferating cells and is scarcein normal vessels. ${ }^{23,27}$ Thesafety of themethod and its effectiveness in developing therapeutic angiogenesishasbeen demonstrated, probably related to the presence of endothelial progenitor cells in the bone marrow, and the possibilities of such cells secreting cytokines that stimulate angiogenesis.

This group treated 45 lower limbs with M BM C and observed significant improvement in the $A B I$, $\mathrm{TCO}^{2}$, increasein painless walking time, increasein the flow with laser Doppler and formation of vessels in arteriography.

Implantation of M BM C improved pain at rest in these patients and the healing of ischemic wounds, demonstrating the efficiency of the procedure. ${ }^{23}$ 


\section{Conclusions}

Although both surgical bypass and endovascular procedures remainseffectivein theimprovement of the blood flow in the ischemic legs, not all patients are candidates for intervention. The effort in basic science laboratories has showed us the safety of thetherapeutic angiogenesis, but weneed to wait for morerandomized trials in order to draw further conclusions.

\section{References}

1. Blauw GJ, Lagaay AM, Smelt AH, et al. Stroke, statins and cholesterol: a meta-analysisof randomized, placebo-controlled, double-blind trials with $\mathrm{HMG}-\mathrm{COA}$ reductase inhibitors. Stroke. 1997;28:946-50.

2. D ormandy J, H eeck L, V ig S. Predictors of early disease in the lower limbs. Semin V asc Surg. 1997;12:109-17.

3. Folkman J. T umor angiogenesis; therapeutic implications. N Engl J M ed. 1971;285:1182-6.

4. T akeshitaS, Z heng LP, Brogi E, et al. Therapeutic angiogenesis. A single intraarterial bolus of vascular endothelial growth factor augments revascularization in a rabbit ischemic hind limb model. J Clin Invest. 1994;93:662-70.

5. Isner J M, Pieczek A, Schainfeld R, et al. Clinical evidence of angiogenesis after arterial gene transfer of phVEGF165 in patient with ischaemic limb. [Report]. Lancet. 1996;348: 370-4.

6. M urohara T, A sahara T, Silver M, et al. N itric oxide synthase modulates angiogenesis in response to tissue ischemia. J Clin Invest. 1998;101:2567-78.

7. Asahara T, M urohara T, Sullivan A, et al. I solation of putative progenitor endothelial cells for angiogenesis. Science. 1997;275:964-7.

8. Shi Q, Rafii S, H ong-D e W u, et al. Evidence for circulating bonemarrow-derived endothelial cells. Blood. 1998;92:362-7.

9. Bhattacharya $V$, Peter $A$, Shi $Q$, et al. Enhanced endothelialization and microvessel formation in polyester grafts seeded with CD $34+$ bone marrow cells. Blood. 2000;95:581-5.

10. Asahara T, M asudaH , T akahashi T, et al. Bonemarrow origin of endothelial progenitor cells responsible for postnatal vasculogenesis in physiological and pathological neovascularization. Circ Res. 1999;85:221-8.

11. I kenaga S, H amano K, N ishida $M$, et al .Autologous bone marrow implantation induced angiogenesis and improved deteriorated exercise capacity in a rat ischemic hindlimb model. J Surg Res. 2001;96:277-83.

12. H irata K, Li TS, N ishida M , et al. Autologous bone marrow cell implantation as therapeutic angiogenesis for ischemic hindlimb in diabetic rat model. Am J Physiol Heart Circ Physiol. 2003;284:H 66-70.

13. Losordo DW, Vale PR, H endel RC, et al. Phase $1 / 2$ placebocontrolled, double-blind, dose-escalating trial of myocardial vascular endothelial growth factor 2 gene transfer by catheter delivery in patientswith chronic myocardial ischemia. [Report]. Circulation. 2002;105:2012-18.
14. Buschmann I, SchaperW. Thepathophysiology of thecollateral circulation (arteriogenesis). J Pathol. 2001;190:338-42.

15. KalkaC, T ehrani H, Laudenberg B, et al. VEG F genetransfer mobilizes endothelial progenitor cells in patients with inoperable coronary disease. Ann Thorac Surg. 2000;70: 829-34.

16. H amano K, Li T S, K obayashi T, et al. Therapeutic angiogenesis induced by local autologous bone marrow cell implantation. Ann Thorac Surg. 2002;73:1210-5.

17. G rines $C L, W$ atkins $M W, H$ elmer $G$, et al. Angiogenic $G$ ene Therapy (AGEN T) T rial in patientswith stableangina pectoris. [Report]. Circulation. 2002;105:1291-7.

18. $H$ eeschen $C$, Lehmann $R, H$ onold J, et al. Profoundly reduced neovascularization capacity of bone marrow mononuclear cellsderived from patients with chronic ischemic heart di sease. Circulation. 2004;109:1615-22.

19. Lederman $R$, Tenaglia $A$, Anderson $R$, et al. D esign of the therapeutic angiogenesis with recombinant fibroblast growth factor-2 for intermittent claudication (TRAFFIC) trial. AJC. 2001;88:192-5.

20. Iba $O$, Hiroaki M, Yoshihisa $N$, et al. Angiogenesis by implantation of peripheral blood mononuclear cells and plateletsinto ischemic limbs. Circulation. 2002;106:2019-25.

21. Al-Khaldi A, Al-Sabti H, Galipeau J, et al. Therapeutic angiogenesis using autologous bone marrow stromal cells: improved blood flow in a chronic limb ischemia model. Ann Thorac Surg. 2003;75:204-9.

22. Kinnaird T, Stabile E, Burnett M S, et al. M arrow-derived stromal cells express genes encoding a broad spectrum of arteriogenic cytokines and promote in vitro and in vivo arteriogenesis though paracrine mechanisms. Circ Res. 2004;94:678-85.

23. Tateishi-Yuyama $E, M$ atsubara $H, M$ urohara $T$, et al. Therapeutic angiogenesis for patients with limb ischaemia by autologous transplantation of bone marrow cell: a pilot study and a randomised controlled trial. Lancet. 2002;360:427-35.

24. Kinnaird T, Stabile E, Burnett MS, et al. Local delivery of marrow-derived stromal cells augments collateral perfusion though paracrinemechanisms. C irculation. 2004;109:1543-9.

25. Assmus $B$, Schächinger $V$, T eupe $C$, et al. T ransplantation of progenitor cells and regeneration enhancement in acute myocardial infarction (TOPCARE-AMI). Circulation. 2002;106:r23-61.

26. Perin EC, D ohmann H F, BorojevicR, et al. T ransendocardial, autologousbonemarrow cell transplantation for severe, chronic ischemic heart failure. Circulation. 2003;107:2294-302.

27. Baumgartner I, Pieczek A, M anor 0 , et al .Constitutive expression of ph VEGF 165 after intramuscular gene transfer promotescollateral vessel development in patientswith critical limb ischemia. Circulation. 1998;97:1114-23.

\section{Correspondence:}

Paulo Eduardo 0 cke Reis

Visconde de Pirajá 414/515, I panema

CEP 22410-002 - Rio de Janeiro, RJ

Tel.: (21) 2287.5327

E-mail: pauloocke@openlink.com.br 